\title{
肺癌患者の栄養評価
} 栄養障害と細胞性免疫能の関連

\section{A Nutritional Assessment of Patients with Lung Cancer}

米田尚弘・江川信一・吉川雅則・堅田 均・成田亘啓・三上理一郎*

\begin{abstract}
要旨：原発性肺癌24例の臨床栄養評価を行なった。身体計測值の低下, Alb, Tf, PA, RBPな どの内藏タンパクの低下が認められ，高率にタンパク・エネルギー栄養障害 $(\mathrm{PEM})$ が存 在した. 血漿アミノ酸分析では, Fischer比(分枝鎖アミノ酸/芳香族アミノ酸)が低值を示 しアミノ酸インバランスの存在が示唆された。遅延型皮䖉反応低下群ではより高度の栄 養障害を認めた. 抗腫瘍機構の1つとしてのNK活性は内臓タンパク及びFischer比と正 の相関を認めた。以上より栄養障害と細胞性免疫能の密接な関連が示唆された.
\end{abstract}

〔肺癌 29(2) : 147 153, 1989〕

Key words : Lung cancer, Nutritional assessment, Cell-mediated immunity.

\section{はじめに}

呼吸器疾患においては，栄養障害が合併する 感染症などのrisk factorである事は, 臨床的に 知られているが，栄養状態が臨床病態に及ぼす

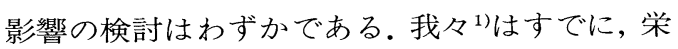
養障害(pulmonary cachexia)が呼吸器疾患に おいても高率に存在する事実を報告した。肺癌 でも，体重減少が重要な子後決定因子の一つで ある事が, 疫学的調査 ${ }^{2}$ で報告されている。一 方, 近年, Blackburn一派 ${ }^{3}$ は人体の構成成分 を, 体脂肪, 筋タンパク及び内臓夕ンパクなど のコンパートメントに区分して，それぞれに特 有のパラメーターを設定して総合的に評価する 栄養評価 (nutritional assessment) の手法を提 唱した. 以後, 栄養評価は消化器外科領域で高 カロリ一輸液の進歩とともに, 著しく進歩した 分野であるが, 肺癌患者の詳細な栄養状態の評 価は行なわれていない.

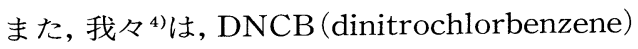

奈良県立医科大学第 2 内科

* 国立相模原病院
遅延型皮膚反応と，NK(natural killer) 細胞活 性を組み合わせる事によって, 肺癌患者の細胞 性免疫能をパターン分類し, 細胞性免疫能が肺 癌患者の治療効果や予後と密接に関連する事を 報告した。

栄養障害と易感染性の関連性は古くから知ら れているが, 肺癌患者における栄養障害と免疫 能の関連性に関する検討は少ない.

今回, 我々は, Blackburnの手法に新たに血漿 アミノ酸分析などを加之て肺癌患者の包括的栄 養評価を行ない, 栄養状態と細胞性免疫能との 関連を検討した。

\section{対象および方法}

未治療の進行期原発性肺癌患者 24 例 (III 期 12 例，IV 期 12 例，平均年令 $63 \pm 13$ 才)について検討 し，健常人 60 例 (平均年令 $58 \pm 20$ 才) をコントロ ールとした (Table 1).

栄養学的パラメーターとしては, Table 2 に示 す様に，身体計測，内臓タンパク，血漿アミノ 酸分析を行なった。身体計測としては, 体重, 
Table 1. Subjects studied.

\begin{tabular}{lrl}
\hline \multicolumn{1}{c}{ Disease } & No. & Mean age \\
\hline Lung cancer (LC) & 24 & $63 \pm 13$ \\
Squamous cell carcinoma & 14 & $67 \pm 11$ \\
Adenocarcinoma & 6 & $60 \pm 14$ \\
Small cell carcinoma & 4 & $51 \pm 9$ \\
Healthy control (Healthy) & 60 & $58 \pm 20$ \\
\hline
\end{tabular}

上腕囲 (arm circumference, AC), 上腕三頭筋皮脂厚 (triceps skinfold, TSF), 入院時の平常時体重に比較 した減少率 (\% loss of body weight) を測定した。標準体重比(\% ideal body weight, \% IBW)は松 木5)の標準体重表に対する百分率で, \%ACおよび\% TSFは金 ${ }^{6)}$ 標準值 に対する百分率で表現した。上腕筋 囲(arm muscle circumference, $\mathrm{AMC})$ はC $-(\pi \times \mathrm{TSF})$ の式に従 って算出し，金の標準值に対する百 分率で表現した。

内臟タンパクの指標としては，血 清アルブミン (serum albumin, Alb)の他に, 代 謝回転の速いトランスフェリン (transferrin, Tf), プレアルブミン (prealbumin, PA), レチ ノール結合蛋白 (retinol-binding protein, RBP)などいわゆる rapid turnover proteins (RTP) を一元免疫拡散法 (パルチゲンプレート， Hoechst社)にて測定した ${ }^{3)}$.

血漿アミノ酸分析は, 早朝空腹時患者血漿を スルホサルチル酸で除蛋白後, 日立835型自動分 析機で測定した。バリン，ロイシン，イソロイ シンからなる分枝鎖アミノ酸(branched chain amino acid, BCAA) とフェニールアラニン, チ ロシン等からなる芳香族アミノ酸 (aromatic amino acid, AAA)のモル比である，いわゆる Fischer比 (BCAA/AAA) ${ }^{8)}$ を算出した.

細胞性免疫能のパラメーターとしては, PPD, DNCBに対する遅延型皮膚反応, ConA, PHAに对するリンパ球幼若化反応，NK活性を 測定した. PPD反応は, 一般診断用PPD液 0.05 $\mu \mathrm{g} / 0.1 \mathrm{ml}$ を皮内接種 48 時間後に型の如く判定
Table 2. Methods for nutritional assessment.

Anthropometric measures
\%Ideal body weight (\%IBW)
\%Loss of body weight
\%Arm circumference (\%AC)
\%Arm muscle circumference (\%AMC)
\%Triceps skin fold (\%TSF)

Biochemical examinations

Serum albumin (Alb)

Rapid turnover protein

Serum transferrin (Tf)

Serum prealbumin (PA)

Serum retinol-binding protein $(\mathrm{RBP})$

Visceral proteins

Plasma amino acids (Fischer ratio: BCAA/AAA)

Cell-mediated immunity

Lymphocyte transformation

PHA

Con A

Delayed-type hypersensitivity (DTH) response

PPD

DNCB

Natural killer (NK) cell activity
した. DNCB反応は感作用 $1 \% \mathrm{DNCB}$ 液を 24 時 間貼付し， 14 日後判定用 $0.1 \% \mathrm{DNCB}$ 液を 48 時 間貼付し判定した。反応なしか紅斑のみを「低 下」, 硬結, 水疱, 壊死形成は「正常」と判定し た.リンパ球幼若化反応は, ConA, PHA添加 後64時間培養し, ${ }^{3} \mathrm{H}-\mathrm{TdR}(0.25 \mu \mathrm{ci} /$ well $)$ を添 加後 8 時間培養し, 液体シンチレーションカウ ンターで取り込みを測定し $\Delta \mathrm{cpm}$ で表現した。

NK活性の測定法は, 以前の報告(10)に従い, K562 を標的細胞とし，比重遠心法にて分離した末梢 血単核球を effector細胞として ${ }^{51} \mathrm{Cr}$ 遊離法にて

$\mathrm{E} / \mathrm{T}$ 比 $=20$ で測定した. 統計処理

平均值の比較は, both-tailed Student's t test で検定した。栄養学的パラメーターと細胞性免 疫能のパラメーターの関連は, 相関係数を算出 して検定した。いずれも $\mathrm{p}<0.05$ 有意とした。

\section{成 績}

身体計測では，\%IBW，\%AMC，\%TSFとも 
Fig. 1. Anthropometric measurements in patients with lung cancer and healthy controls.
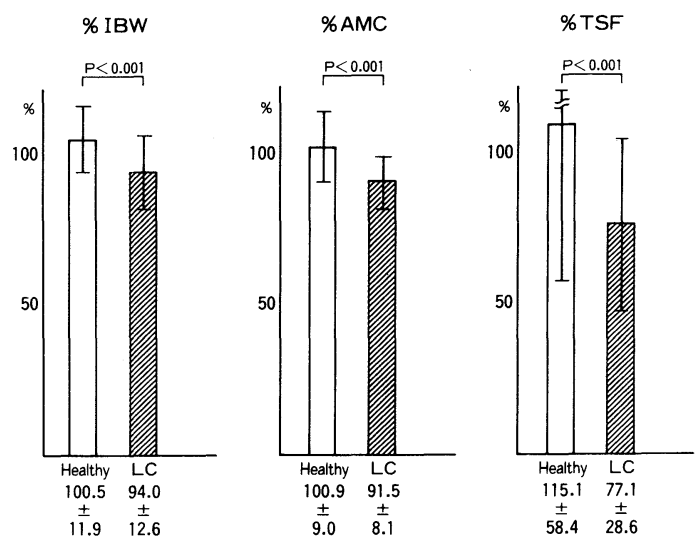

Fig. 3. Plasma amino acids in patients with lung cancer and healthy controls.

BCAA : branched-chain amino acids,

AAA : aromatic amino acids.
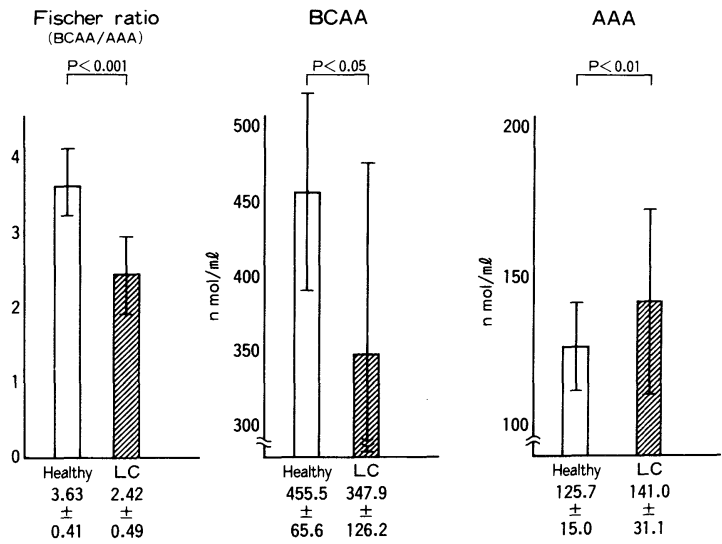

軽度一中等度の低下を示した (Fig. 1)。体脂肪 量 (\% TSF)の減少に比べ，筋タンパク量 $(\%$ $\mathrm{AMC})$ が比較的保持されている傾向を認めた。

内藏タンパクでは，アルブミンは健常人に比 べ有意に低值を示し，トランスフェリン，プレ アルブミン，レチノール結合蛋白などのRTPも 著明に低值を示した (Fig. 2)。

血漿アミノ酸分析では, 健常人に比べて $\mathrm{BCAA}$ 有意の低下, $\mathrm{AAA} の$ 有意の上昇を認め BCAA/AAA 比であるFischer 比は2.42 00.49 と健常人のそれ $(3.63 \pm 0.41)$ に比べ著明な低值 を示した。この成績は肺癌患者におけるアミノ
Fig. 2. Visceral proteins in patients with lung cancer and healthy controls.

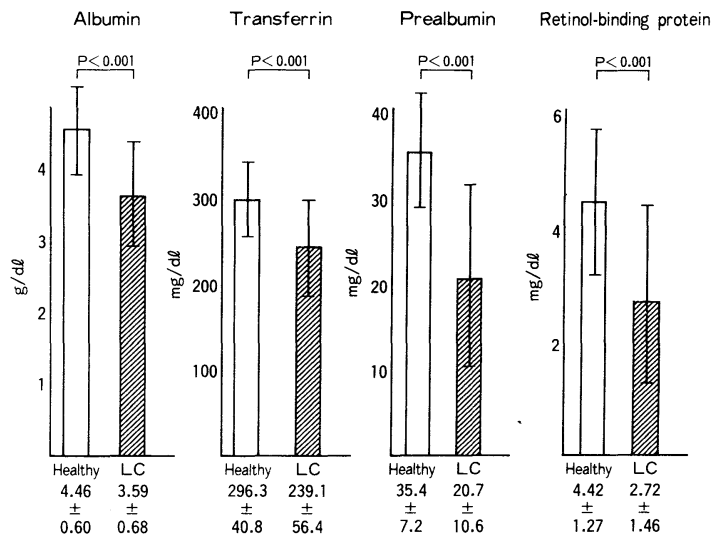

Table 3. Cell-mediated immunity in patients with lung cancer.

\begin{tabular}{lcc}
\hline & Lung cancer & Healthy controls \\
\hline \% reduction of DTH to & & \\
PPD & $25^{*}$ & 5 \\
DNCB & $61^{*}$ & 8 \\
& & \\
Lymphocytes transformation & & \\
response (cpm) & $18815 \pm 8484^{*} *$ & $41254 \pm 7699$ \\
Con A & $21867 \pm 9752^{* *}$ & $50057 \pm 5576$ \\
PHA & & \\
& $33.0 \pm 17.0^{* * * *}$ & $42.0 \pm 17.0$ \\
NK activity (\%) & & \\
\hline$* \mathrm{P}<0.001$ by $\chi^{2}$ test $* * \mathrm{P}<0.001$ & $* * * \mathrm{P}<0.05$ by Student's t test
\end{tabular}

酸インバランスの存在を示唆している (Fig. 3).

上述の栄養学的パラメーターによって検出さ れる栄養障害の頻度を検討した。 \%IBWが $80 \%$ 以下の中等度以上の栄養障害を呈する症例は肺 癌患者の $30 \%$, アルブミンが $3.5 \mathrm{~g} / \mathrm{d} 1$ 以下は 40 \%，レチノール結合蛋白が $3.15 \mathrm{mg} / \mathrm{dl}$ (健常人の 平均值一標準偏差值) 以下は $61 \%$ で, Fischer比 が3.2以下 (健常人の平均值一標準偏差值)の症 例は $100 \%$ であった。

肺癌患者の細胞性免疫能の検討 (Table 3) で は，PPD，DNCBに対する遅延型皮虞反応の低 下率は各々 $25 \% ， 61 \%$ で健常人に比べて有意に 高率であった。ConA，PHAに対するリンパ球 幼若化反応も健常人に比べ著明に低值を示した. 
Table 4. Relationship between nutritional status and delayed-type hypersensitivity response.

\begin{tabular}{lccccc}
\hline & \multicolumn{3}{c}{ DTH to } \\
\cline { 2 - 3 } \cline { 5 - 6 } \cline { 5 - 6 } \% loss of body weight & normal & reduced & & normal & reduced \\
\cline { 2 - 3 } Albumin & $3.5 \pm 3.5^{*}$ & $13.6 \pm 8.8^{*}$ & & $5.7 \pm 7.9$ & $6.6 \pm 6.3$ \\
Transferrin & $3.8 \pm 0.63^{*}$ & $3.2 \pm 0.69^{*}$ & & $3.67 \pm 0.77$ & $3.56 \pm 0.51$ \\
Prealbumin & $242.0 \pm 59.8$ & $196.8 \pm 44.5$ & & $230.3 \pm 63.2$ & $225.8 \pm 54.8$ \\
Retinol-binding protein & $21.3 \pm 8.9$ & $13.9 \pm 13.0$ & & $20.7 \pm 10.2$ & $18.9 \pm 10.4$ \\
Fischer ratio & $2.71 \pm 1.32$ & $2.00 \pm 1.64$ & & $2.84 \pm 1.44$ & $2.48 \pm 1.37$ \\
\hline
\end{tabular}

$* \mathrm{P}<0.05$

Fig. 4. Relationship between visceral proteins and NK activity in patients with lung cancer.
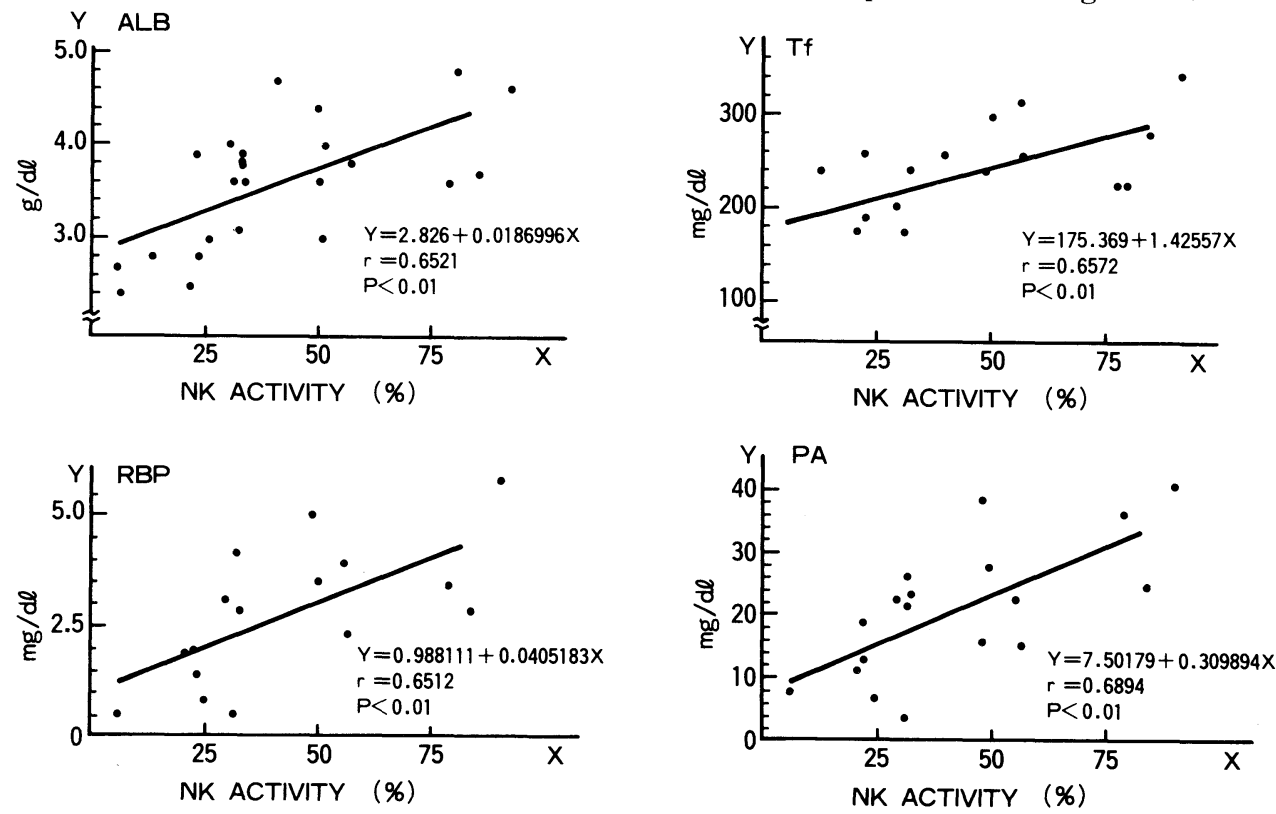

Fig. 5. Relationship between Fischer ratio and NK activity in patients with lung cancer.

また，NK活性も健常人に比べ有意に低值を示 した.

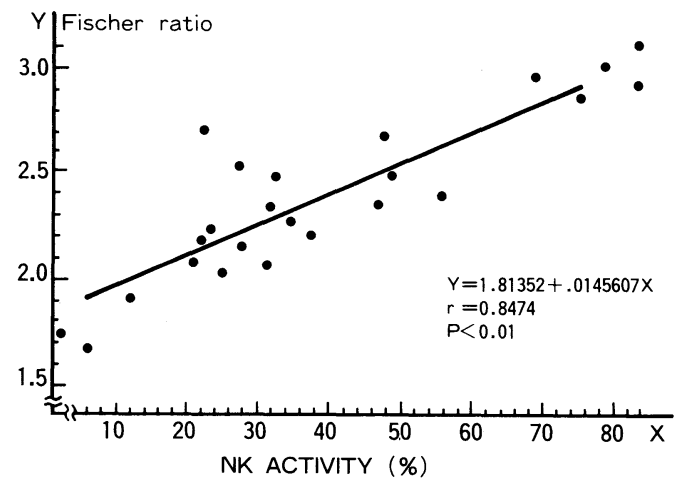

遅延型皮膚反応と栄養状態の関連をみると， PPD反応低下群は, 正常群に比べて\% loss of body weightが有意に高く，アルブミンが有意 に低下し，他のRTPやFischer比も低值傾向を 認めた。DNCB反応低下群も正常群に比へ，統 計学的有意差を認めないがPPD反応と同様の 傾向を認めた (Table 4).

NK活性と内臟タンパクの関連性をみると, アルブミン，トランスフェリン，プレアルブミ ン, レチノール結合蛋白とも NK活性と正の相 
関を認めた (Fig. 4).

Fig. 5に示す様に，アミノ酸インバランスの 指標であるFischer (BCAA/AAA) 比は, NK活 性と有意の正の相関を認めた。

\section{考 察}

進行癌患者が, いわゆる癌悪液質 (cancer cachexia) といわれる栄養障害に陥る事は, 臨床 上しばしば認められ, 栄養状態が, 患者の全身 状態や，治療効果，予後などと関連することは， 漠然と知られていた。消化器癌患者の栄養状態 を改善する目的で栄養治療を, 術前後, 化学療 法に対する支持療法として行なうことは, 今日 一般化しつつある。肺癌治療に際しても，的確 に栄養状態を把握する事は臨床上重要であると 思われるが, 従来, この分野の検討は極めて少 ない.

今回の検討では, 肺癌患者においても高率に タンパク・エネルギー栄養障害 (protein energy malnutrition, PEM) が存在する事実が示され た。身体計測值 (体脂肪, 筋タンパク量の低下) や内臟タンパク (血清アルブミン, RTPの低下) の成績を総合すると, 今回対象とした肺癌患者 は, 軽度のKwashiorkor椂低アルブミン血症を 伴ったmarasmus(タンパク質とエネルギーの 欠乏状態)と考えられる。栄養障害の原因は明ら かではないが，食欲不振による食事摂取量低下， 腫瘍によるエネルギー消費の増大, 糖新生充進, タンパク合成, 分解の六進など多くの要因が複 合していると推測 ${ }^{11}$ される.

血漿アミノ酸分析は, Holt ${ }^{12}$ によって飢餓小 児において検討され，一定のパターンを示す事 が報告されて以来, 栄養学的パラメーターの 1 つと考えられた。そして，Fischerにより肝性脳 症患者に扔いて提唱されたBCAA/AAA比はア ミノ酸インバランスの指標として重要視される 様になった. 日本では, 武藤ら ${ }^{13)}$ が肝疾患で検討 し, Fischer比で血清アルブミン值とよく相関す るという栄養学的パラメーターとしての有用性 を示した。しかし, 癌患者における血漿アミノ 酸分析の報告は少ない. Ching ${ }^{14)}$ は頭頸部腫 瘍患者のアミノ酸分析を行い, BCAAの低下を
報告している．今回対象とした肺癌患者では, 体重や筋タンパクは比較的保持され, 重篤な cancer cachexiaの状態には到っていないが,ア ミノ酸インバランスがすでに全例に検出された。 その原因は明らかではないが, 担癌状態におけ る異化元進時には, 敗血症 ${ }^{15)}$ や外科侵襲時 ${ }^{16)}$ と 同様BCAAが, 筋肉内で直接酸化されてエネル ギー源となったり, 糖新生の立進下でアラニン などの糖原性アミノ酸の基質になり, 血漿中で 低下し，筋崩壊で流出するが肝で利用されない AAAが血漿中で増加すると推測される。このよ うに, 血漿アミノ酸分析によるFischer比の測定 が，肺癌患者の栄養評価や栄養管理に重要な一 指標になりうることを示唆している.

栄養障害が細胞性免疫能に及ぼす影響につい

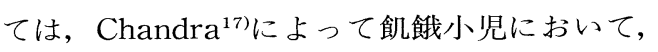
Law $^{18)}$, Bistrianら ${ }^{19}$ によって外科患者におい て比較的最近注目され始めた. 一方, 従来, 癌 患者の細胞性免疫能の低下に関する報告は数多 いが, 癌患者の細胞性免疫能の低下を栄養障害 の観点から検討した報告はわずかである。 Copelandら ${ }^{20}$ は, 主として消化器癌患者におい て血清アルブミンの低下と遅延型皮膚反応の低 下の関連性および治療効果などとの関連性を報 告している。我々の検討では, 遅延型皮膚反応 の低下と内臓タンパクの低下だけでなく, Fischer比の低下に反映されるアミノ酸インバラン スとの関連性が認められた点は興味深い.

NK細胞は, 未感作リンパ球がある種の腫瘍 細胞に対して細胞障害性を示す現象により発見 され, 腫瘍やウイルス感染に対する生体防御機 構の一つとして重要視され21)ている.すでに, 我々は4), 肺癌患者の細胞性免疫能を検討し, 特 にNK活性が, 全身状態や治療効果・予後と深く 関連する事実を報告した。 今回, NK活性とアミ ノ酸インバランスや内蔵タンパクとの密接な相 関を認めたことは，アミノ酸・タンパク代謝障 害に基づく栄養障害が肺癌患者における細胞性 免疫能低下の要因の 1 つである可能性を示唆す る新たな知見であると考える。 


\section{結 語}

原発性肺癌患者24例の栄養評価と細胞性免疫 能を検討し，以下の成績をえた。

1. 身体計測では，\%IBW，\%AMC，\%TSF とも健常人に比べ有意に低值を示した。

2.内臓タンパクでは, アルブミンに加えて, RTPも低値を示した。

3. 血漿アミ八酸分析では, BCAAの低下, AAAの上昇により Fischer比 $(\mathrm{BCAA} / \mathrm{AAA}) の$ 著明な低下を認めた。

4. 遅延型皮虞反応は, PPD, DNCBに対し て各々 $25 \% ， 61 \%$ 低下した。

5.リンパ球幼若化反応は健常人に比べ有意 に低值を示した。

6. NK活性は健常人に比べ有意に低值を示
した。

7. PPD反応低下群は正常群に比べアルブ ミン，\%Loss of body weightの有意の低下や Fischer比の低下傾向を認めた.

8. NK活性はFischer比や内臓タンパクと 良好な正の相関を認めた。

以上より，肺癌患者では高率に栄養障害を認 め, 細胞性免疫能の低下は, 内臓タンパクの低 下ゃアミノ酸インバランスと密接に関連する事 が示唆された。

(本論文の内容は第28回日本肺癌学会総会において発表 した. 尚, 本研究の一部は文部省科研費63770514の補助 をえた.）

9) Yoneda, T., Mikami, R., Sakaguchi, et al. : The relationship between natural killer cell activity and delayed-type hypersensitivity reaction to 2.4-dinitrochlorbenzene in the spectrum of chronic, intractable pulmonary tuberculosis. Tubercle, 68:59-64, 1987.

10) Yoneda, T., Kasai, M., Ishibashi, J., et al. : NK cell activity in pulmonary tuberculosis. Br. J. Dis. Chest, 77 : 185-188, 1983.

11) Bistrian, B.R. : Some practical and theoretic concepts in the nutritional assessment of the cancer patient. Cancer, 58:1863-1866, 1986.

12) Holt, L.M., Snyderman, S.E., Norton, P.M. et al. : The plasma aminogram in Kwashiorkor. Lancet, 2 : 1343-1348, 1963.

13）武藤泰敏, 吉田 貴, 山藤正広：慢性肝不全の 栄養治療。日本医事新報, 3101：3-9，1984。

14) Ching, N., Grossi, C., Tham, G., et al. : Plasma amino acid and serum unesterified fatty acid deficits and the effect of nutritional support in chemotherapy treatment. Surgery, 95:730-738, 1984.

15) Freund, H,R., Ryan, J.A. and Fischer, J.E. : Amino acid derangements in patients with sepsis. Ann. Surg., 188 : 423-430, 1978. 
16) Dölp, R., Fekl, W. and Ahnefeld, F.W. : Free amino acids in plasma in the post-traumatic period. Infusiontherapie, $2: 321-324,1975$.

17) Chandra, R.K. : Immunocompetence in undernutrition. J. Pediatr., $81: 1194-1200$, 1972.

18) Law, D.K., Dudrick, S.J. and Abdou, N.I. : The effect of dietary protein depletion on immunocompetence. Ann. Surg., 179 : 168173, 1974.

19) Bistrian, B.R., Blackburn, G.L., Scrimshaw, N.S. : Cellular immunity in semistarved sta- tus in hospitalized adults. Am. J. Clin. Nutr., 28 : 1148-1155, 1975.

20) Daly, J.M., Dudrick, S.J., Copeland, E.M. : Evaluation of nutritional indices as prognostic indicators in the cancer patient. Cancer, $43:$ 925-931, 1979.

21) Kasai, M., Yoneda, T., Habu, S., et al. : In vivo effect of anti-asialo GM 1 antibody on natural killer activity. Nature, 291:334335, 1981.

(原稿受付 1988 年 7 月 1 日 /採択 1988 年 8 月 24 日)

\title{
A Nutritional Assessment of Patients with Lung Cancer
}

\author{
Takahiro Yoneda, Shinichi Egawa, Masanori Yoshikawa, \\ Hitoshi Katada, Nobuhiro Narita and Riichiro Mikami
}

Second Department of Internal Medicine, Nara Medical University, President, National Sagamihara Hospital

The Nutritional status of 24 patients with lung cancer and 60 healthy subjects was studied. A decrease in anthropometric parameters and in visceral proteins such as Alb, Tf, PA, $\mathrm{RBP}$, suggested a high incidence of protein energy malnutrition (PEM) in lung cancer patient. Plasma amino acids analysis showed, that the Fischer ratio (BCAA/AAA) was reduced, which may suggest the existence of an imbalance of plasma amino acids in patients with lung cancer.

A subgroup with reduced delayed-type hypersensitivity reaction was shown to be more malnourished than those with normal delayed-type hypersensitivity reaction. NK cell activity, which has been shown to play an important role in the defense mechanism against tumor, correlated significantly with visceral proteins and the Fischer ratio. These findings may suggest the relationship between malnutrition and cell-mediated immunity in patients with lung cancer. 